\title{
An Analysis of Tax Avoidance in Food Beverage Companies Registered in Indonesia Stock Exchange
}

\author{
Dwi Dewianawati ${ }^{1 *}$, Erry Setiawan ${ }^{2}$ \\ ${ }^{1,2}$ Department of Managament, Mayjend Sungkono University \\ *Corresponding author: \\ Email: dwidewianawati@gmail.com
}

\begin{abstract}
.
The increasing growth in the food and beverage company indicates the high profitability of the company. Profitability describes the condition in which a company can generate profits at a certain level of sales, assets, and share capital. An increase in profitability requires companies to pay high taxes as well, but in reality, taxpayers do not comply with the tax obligations through tax avoidance attempts. This study aims to determine the effects of profitability and leverage simultaneously on tax avoidance. It is to assess the impact of profitability and leverage partially on tax avoidance. The population used in this study was a food and beverage company registered in the Indonesia Stock Exchange (IDX) during 2017-2019. Furthermore, this study utilized a purposive sampling technique as its sampling technique with a sample size of 13 companies. Multiple Regression Model was employed to determine the effect of independent variables on the dependent variable.Based on the study results, it could be concluded that the variables of Return on Assets (ROA) and leverage simultaneously related to tax avoidance practices in food and beverage companies registered in the Indonesia Stock Exchange (IDX). The variable of Return on Asset (ROA) ratio did not significantly affect tax avoidance in food and beverage companies in the Indonesia Stock Exchange. Meanwhile, leverage significantly affected tax avoidance in food and beverage companies in the Indonesia Stock Exchange. The leverage variable had a dominance effect on tax avoidance in food and beverage companies in the Indonesia Stock Exchange.
\end{abstract}

Keywords: Profitability, leverage, tax avoidance

\section{INTRODUCTION}

The economic growth of a country cannot be separated from the investment, which can be measured by the level of the country's capital market development. A capital market, as one of the elements of the economic system, contributes to economic and business growth and development. The dynamics of the developed countries' economies are always marked by the rapid development of the capital market industry, including in equity market, bond market, and derivative market. The Indonesia Stock Exchange (IDX) forms a capital market in Indonesia. The Indonesia Stock Exchange has a vital role as a means for the public to invest, an alternative investment practice. For companies, the IDX facilitates companies to get additional capital by going public, i.e., the activities of offering shares or other securities carried out by issuers (companies that go public) to the public based on procedures regulated by the Capital Market Law and its Implementing Regulations (Basir, 2012: 28).

The capital market is defined as a market for various long-term financial instruments that can be traded, either in debt or equity. Financial instruments traded in the capital market include stocks, bonds, warrants, rights, convertible bonds, and various derivative products, such as options (put or call). Taxes are one of the most essential and considerable sources of state revenue aimed at financing state development. The largest state revenue should be kept optimally increased so it can bring a positive impact on the country's growth rate, and the development implementation can run well. It is expected that it can increase the compliance of taxpayers in carrying out their tax obligations in accordance with applicable tax regulations. Regarding the company management, which generally does not want a reduction in purchasing 
power, they will try to make cost efficiency to optimize company profits, including tax payments. In fact, taxpayers' noncompliance can lead to tax avoidance attempts. Generally, tax avoidance can be divided into two, which are tax evasion and tax avoidance. Tax evasion is the act of deliberate tax evasion associated with unlawful means or attempts to reduce or eliminate the tax burden to lower the tax rate. Meanwhile, tax avoidance is an act or attempt to avoid taxes legally by not violating the tax laws. In this case, taxpayers try to reduce the amount of tax payable by finding regulatory weaknesses. It is attributed to the imperfection of tax laws, which can then be abused by taxpayers.

Therefore, the pros and cons of tax avoidance appear somewhat complicated. On the one hand, it is permissible to do tax avoidance by taking advantage of existing taxation regulatory loopholes, but on the other hand, state revenue will be less than what the state is supposed to gain. Tax authorities try to enforce definite boundaries between tax avoidance and tax evasion. The government also seeks to prevent taxpayers from making use of the loopholes created by tax regulations. The purpose of those efforts is to anticipate taxpayers using an assessment structure for legal status that seems ambiguous so that it can be accepted as a way of tax planning, yet in practice, it violates the regulations (Annisa and Kurniasih, 2012: 123)

Profitability is a measure of a company's performance. Profitability describes the condition in which a company is capable of generating profits at a certain level of sales, assets, and share capital. Profitability consists of several ratios, one of which is ROA (Return on Assets). Performance measurement using ROA signifies that the capital invested in all assets can generate profits. A negative ROA occurs because the company's profit is in an adverse condition or at a loss. Companies that earn profits are assumed not to commit tax avoidance because they can manage their income and tax payments (Maharani and Suardana, 2014: 80).

Profitability has an effect on profit management as Guna and Herawati (2010) in their research prove that the impact of adequate corporate governance mechanisms, auditor independence, audit quality, and other factors on profit management indicates that leverage, audit quality, and profitability affect profit management. In accordance with the variables used in this study, it can be concluded that profitability may also have a significant effect on tax avoidance. It can be inferred as profit management refers to a method employed by managers to commit tax avoidance.

Besides, the factor affecting tax avoidance is leverage. Companies with high leverage risk to suffer large losses. The higher the leverage ratio, the more significant the proportion of company funding that is financed from debt. Therefore, the company tends to violate the debt agreement when it experiences a default, meaning that it cannot pay off its obligations at the maturity date due to financial difficulties. According to Noor (2010: 190), leverage refers to total debt divided by total assets.

The increasing growth in the food and beverage company indicates the high profitability of the company. Profitability describes the condition in which a company is capable of generating profits at a certain level of sales, assets, and share capital. An increase in profitability requires companies to pay high taxes as well, but in reality, taxpayers do not comply with the tax obligations through tax avoidance attempts.

\section{Literature Review}

\section{Tax avoidance}

Tax avoidance is a process of controlling actions to avoid the consequences of unwanted tax imposition. In this case, there is no violation of the law committed, and on the contrary, tax savings are obtained by regulating actions that prevent the tax imposition through 
controlling the facts in such a way to avoid the higher tax imposition or no tax entirely (Zain, 2008: 49).

According to Dyreng (2009: 95), tax avoidance is defined as all forms of activities that affect tax obligations, both actions requested by taxes or unusual activities to reduce taxes. Commonly, tax avoidance is committed by exploiting the weaknesses of tax law.

According to Mardiasmo (2009: 89), "Tax avoidance is an attempt to reduce the tax burden by not violating existing laws." Comparatively, Bovi (2008: 96) argues that "Tax avoidance is an attempt to reduce taxes, but still comply with the provisions of tax regulations, such as taking advantage of exclusions and deductions that are allowed as well as postponing taxes that have not been regulated in the applicable tax regulations."

Budiman and Setiyono (2012: 75) affirm that "Tax avoidance is a deliberate action taken by a company to reduce the tax payments to increase a company's cash flow."

Hence, tax avoidance is intentionally committed by companies to minimize tax payments that must be paid and increase the company's cash flow. Likewise, Godfrey (2010: 113) states that "The benefit of tax avoidance is to increase tax savings which potentially reduce tax payments so that it will increase cash flow."

This tax evasion has narrowed the tax base on income tax and resulted in a considerable loss of potential tax revenue, which can be used to reduce the burden on the state budget deficit. According to Slemrod in Prakosa (2014: 1-27), "An additional factor for companies in complying with taxes is the separation of ownership and control within the company. It can lead to corporate tax decisions that reflect management's interests. It causes tax avoidance in companies. "Dewi and I Ketut (2014: 249) state that "The basis for understanding tax avoidance is agency framework. Tax avoidance is considered as a practice that transfers welfare from state to shareholders. "

They also state that tax avoidance practices provide opportunities for management to carry out activities designed to hide the company's bad news or even mislead the investors. Law on General Provisions and Tax Procedures (UU KUP) explains that tax is one of the means and rights of each taxpayer to participate in state administration and development. However, tax is considered as an investment burden by business people. Therefore, it is natural for companies/business people to avoid a tax burden by carrying out effective tax planning.

Tax avoidance can be measured by CASH ETR/Cash Effective Tax Rate, which is capable of identifying the aggressiveness of corporate tax planning carried out using fixed or contemporary differences (Chen et al., 2010: 41-61). This study used CASH ETR as a proxy of tax avoidance. CASH ETR calculates tax payments from the cash flow statements to identify how much tax is paid by the company. CASH ETR is the ratio of tax payments in cash to the company profits of income tax. Mathematically, CASH ETR can be formulated as follows:

$$
\text { Cash Effective Tax Rate }(\text { CASH ETR })=\frac{\text { Tax Payment }}{\text { Bernth B Before Tox }}
$$

\section{Profitability}

Profitability is a "ratio to assess company's ability to generate profits. This ratio also provides a measure of management effectiveness level in a company. Basically, the ratio is used to show the company's efficiency" (Kasmir 2008: 196).

Meanwhile, according to Mamduh and Abdul (2009: 83), "Profitability is the ability of a company to generate profits at the level of sales, assets, and certain share capital."

The company profitability becomes one of the bases for assessing the company condition for an analytical tool to evaluate it is required. The profitability ratio analysis tool 
aims to measure management effectiveness based on the returns obtained from sales and investment.

According to Supriyono (2008: 85), profitability assessment is defined as "the process of determining how well business activities are carried out to achieve strategic objectives, eliminate waste and provide timely information to carry out continuous improvements."

A profitability ratio is a "ratio to assess the company's ability and seek profits. Companies that gain profits are assumed not to commit tax avoidance because they are capable of managing their income and tax payments" (Maharani \& Suardana, 2014: 525-539).

This ratio also provides a measure of management effectiveness level in a company. It is indicated by the profit generated from sales and investment income. The main point is that the use of this ratio denotes the efficiency of the company. Comparable to other ratios, the profitability ratio also has its goals and benefits, not only for the business owner or management but also for parties outside the company, especially those who have a relationship or interest with the company.

The higher the ROA value, the higher the value of the company's net income and profitability. A company with high profitability has the opportunity to position itself in tax planning, reducing the amount of tax liability. Meanwhile, according to Mamduh and Abdul (2009: 85), "Profitability is the company's ability to generate profits from the sale of certain assets and share capital."

Profitability can be measured using Return On Assets (ROA). "Return On Assets (ROA) is employed to measure the extent to which the company effectiveness in terms of utilizing its resources." (Siahaan, 2008: 86). Dendawijaya (2008: 74) asserts that "ROA describes the management ability to obtain profits. The higher the ROA, the higher its profits, so the better the management of the company's assets."

The higher the ratio indicates that "the company is more effective in utilizing assets to generate net profit after tax, which also means that the company's performance is better" (Tandelilin, 2010: 73).

It further increases the company's attractiveness to investors. The increased attractiveness of the company makes the company more attractive to investors, for the rate of return will be even greater. It also affects the share price of the company in the capital market, which also increases. In other words, ROA affects the company's share price. These results prove that investors still consider ROA to make share investment decisions. In this study, the profitability ratio is measured by examining the Return on Assets (ROA). Mathematically, ROA can be formulated as follows:

\section{Leverage}

$$
\text { Return on Assets }(\mathrm{ROA})=\frac{\text { Net IncomeAfter Tax }}{\text { Total Assets }} \times 100 \%
$$

Leverage is "the ratio that measures the ability of both long-term and short-term debt to finance the company's assets. Leverage is a source of corporate funding from the external side of debt. Such debt is long-term debt" (Kurniasih and Sari, 2013: 63).

According to Bambang (2010: 375), "Leverage can be defined as the use of assets or funds, which the company shall cover fixed costs or pay fixed expenses." Sudana (2011: 157) posits that "Leverage arises because companies in their operations use assets and sources of funds that cause fixed expenses for the company." According to Kuswadi (2008: 182), "Leverage is the ability to pay the long-term debt, both principal and interest."

Meanwhile, according to Agus and Martono (2009: 295): "Leverage refers to the use of assets and sources of funds by companies, where the company should spend fixed costs or fixed expenses in using these assets or funds. The use of these assets or funds is ultimately intended to increase potential profits for shareholders".

Based on the definition explained, leverage can be determined as the utilization of assets or funds for company operations that causes expenses. 
Godfrey et al. (2010: 508) states that leverage is "The use of debt to finance an entity, often measured as the amount of debt to equity or as the amount of liabilities to assets." Leverage indicates the use of debt to finance investments and assets owned by the company. Leverage can be defined as the picture of the company's capability to utilize assets or funds with fixed expenses to increase the income levels for company owners. Leverage shows to what extent the company is financed by debts or external parties with the company's capabilities as identified by its capital.

Companies with high tax obligations decide to be in debt to reduce taxes. Deliberately, companies owe money to reduce the tax burden, and it can be categorized as tax aggressiveness. The higher the value of the leverage ratio, the higher the amount of funding from third party debts used by the company and the interest expense caused by the debts. The higher interest expense can reduce the company's tax burden.

Richardson and Lanis (2009: 153) state that "the higher the debt value of the company, the lower the company's CASH ETR value."

Leverage refers to asset utilization and sources of funds by companies, where the utilization of these assets or funds is intended to increase potential profits for the company's stakeholders. Companies that use debts should pay the interest. Deductible interest expenses can reduce the company's taxable profit. Decreased taxable profit can reduce the amount of tax that must be paid by a company.

Hence, leverage can be calculated using the proxy of total debt divided by total assets (Mulyani and Endang, 2014: 43). The following is a formula to calculate leverage:

\section{Debt to Equity Ratio (DER) $=\frac{\text { Totel Lisbiltles }}{\text { Total Equuty }}$}

\section{Effects of Profitability on Tax Avoidance}

ROA is an indicator reflecting the company's operational performance and measuring the net profit generated from asset utilization. The higher the ROA, the higher the productivity of assets, and the level of company profitability are. Chen et al. (2010: 75) state that companies with a high level of profitability have the opportunity to carry out efficient efforts in tax payment obligations through tax avoidance practices, and ROA has a negative effect on tax avoidance. Prakosa (2014) suggests that if ROA increases, tax avoidance practices will decrease, while the research results conducted by Meilinda and Cahyonowati (2013) contend that companies that operate efficiently will get tax subsidy in the form of a lower effective tax rate compared to companies operating at low efficiency.

\section{Effects of Leverage on Tax Avoidance}

Companies with high leverage risk to suffer large losses. The higher the leverage ratio, the more significant the proportion of company funding financed from debts. Consequently, they tend to violate debt covenants when experiencing default, incapable of paying off their obligations due to financial difficulties (Dina, 2012: 64).

Companies can use debts to fulfill their operational and investment needs. However, debts can incur a fixed rate of return for the company, called interest. The greater the company's debt, the smaller the tax burden would be because the added element of business costs and the reduction is highly significant for companies that are subject to high taxes. Therefore, the higher the interest rate, the greater the profit that the company would gain from using the debts. The benefits provided from tax savings due to interest have implications for the increased use of corporate debts. Ozkan in Suyanto (2012: 53) proved that companies with high tax obligations would choose to be in debt to reduce taxes. Deliberately, companies owe to minimize the tax burden, and it can be categorized as tax avoidance. 


\section{RESEARCH METHODS}

\section{Population and Sample}

According to Sugiyono (2009: 65), the population is a generalization area consisting of objects or subjects with specific qualities and characteristics determined by researchers to be studied, and then a conclusion can be drawn. The population used in this study included 17 food and beverage companies registered in the Indonesia Stock Exchange (IDX) during 2017-2019.

This study applied a purposive sampling technique. Purposive sampling is a sampling technique using specific considerations/criteria. From the population of food and beverage companies registered in the Indonesia Stock Exchange, the samples were taken using purposive sampling with the following criteria:

1. Food and Beverage companies registered in the Indonesia Stock Exchange (IDX) during 2017-2019.

2. Companies that issue Financial Statements consecutively during 2017-2019.

3. Financial statements provide information on the required variables, i.e., profitability and leverage.

Table 1.List of Criteria for Food and Beverage Companies in the IDX as Samples

\begin{tabular}{|l|l|c|}
\hline No & \multicolumn{1}{|c|}{ Criteria } & $\begin{array}{c}\text { Companies that did not } \\
\text { fulfill the criteria }\end{array}$ \\
\hline 1 & $\begin{array}{l}\text { Food and Beverage companies registered in the } \\
\text { Indonesia Stock Exchange (IDX) during 2017-2019. }\end{array}$ & 2 Companies \\
\hline 2 & $\begin{array}{l}\text { Companies that issue Financial Statements } \\
\text { consecutively during 2017-2019. }\end{array}$ & 2 Companies \\
\hline 3 & $\begin{array}{l}\text { Financial statements provide information on the } \\
\text { required variables, i.e., profitability and leverage. }\end{array}$ & 0 \\
\hline
\end{tabular}

Source: processed data, 2020

Based on the table above, four companies cannot fulfill the sample criteria, including PT Akasha Wira International, Tbk (ADES), PT. Aqua Golden Mississippi Tbk (AQUA), PT. Davomas Abadi Tbk (DAVO), and PT. Sekar Bumi Tbk (SKBM).

Table 2.List of Food and Beverage Company on the IDX as Samples

\begin{tabular}{|c|l|c|}
\hline No. & \multicolumn{1}{|c|}{ Company Name } & Code \\
\hline 1 & PT. Wilmar Cahaya Indonesia, Tbk & CEKA \\
\hline 2 & PT. Delta Djakarta, Tbk & DLTA \\
\hline 3 & PT. Indofood Sukses Makmur, Tbk & INDF \\
\hline 4 & PT. Mayora Indah, Tbk & MYOR \\
\hline 5 & PT. Multi Bintang Indonesia, Tbk & MLBI \\
\hline 6 & PT. Sekar Laut, Tbk & SKLT \\
\hline 7 & PT. Siantar Top, Tbk & STTP \\
\hline 8 & PT. Tiga Pilar Sejahtera Food, Tbk & AISA \\
\hline 9 & PT. Ultrajaya Milk Industry \& Trading Company, Tbk & ULTJ \\
\hline 10 & PT. Tri Banyan Tirta Tbk & ALTO \\
\hline 11 & PT. Indofood CBP Sukses Makmur Tbk & ICBP \\
\hline 12 & PT. Prashida Aneka Niaga, Tbk & PSDN \\
\hline 13 & PT. Nippon Indosari Corporindo Tbk & ROTI \\
\hline
\end{tabular}

Source: www.sahamok.com. April 12, 2020

\section{Research Variables and Operational Definition of Research Variables Independent Variable (X)}

The Independent variable is a variable that causes or affects other variables. (Sugiyono, 2010: 58). The independent variables in this study include:

\section{Profitability $\left(X_{1}\right)$}


Profitability is a "ratio to assess company's ability to generate profits. This ratio also provides a measure of management effectiveness level in a company. Basically, the ratio is used to show the company's efficiency" (Kasmir 2008: 196).

In this study, profitability used the proxy ROA (Return on Assets), which compares net income and total assets at the end of the period, which is used as an indicator of a company's ability to generate profits. (Siahaan, 2008: 86). ROA is an indicator utilized to reflect the company's operational performance, and it can be used as a measure of a company's net profit from asset use. The higher the ROA value, the higher the productivity of assets, and the level of company profitability (Chen et al., 2010: 96). With the high profitability, the company has the opportunity to make efficiency efforts in tax payment obligations through tax avoidance practices. This formula calculates ROA:

\section{Leverage $\left(\mathrm{X}_{2}\right)$}

\section{ROA $=\frac{\text { Net Income After Tex }}{\text { Totel Assets }} \times 100 \%$}

Leverage is a source of external company funding from debt, which is long-term debt. Leverage can be measured using the ratio of total long-term liabilities to total assets. Leverage is a ratio that measures the long-term and short-term debt-paying ability to finance a company's assets. (Kurniasih and Sari, 2016: 76). If liabilities were more significant than assets, the ratio of liabilities would be greater. In this study, leverage can be measured from total debt, both long and short, with total DER (Debt to Equity). The formula for calculating leverage is as follows:

$$
\text { DER }=\frac{\text { Total Llab Ittles }}{\text { Total Bquity }}
$$

\section{Dependent Variable (Y)}

The dependent variable is a variable that is affected by the other variables. (Sugiyono, 2009:60). The dependent variable in this study included tax avoidance. Tax avoidance can be measured using CASH ETR (Cash Effective Tax Rate) proxy, which calculates the payment on cash to profit before tax. The CASH ETR proxy is used to reflect short-term tax avoidance practices paid in cash (Dyreng et al., 2010: 103). The greater the CASH ETR, the lower the level of tax avoidance could be indicated. The formula for calculating tax avoidance is as follows:

\section{CASH ETR $=\frac{\text { Tax Parmant }}{\text { Barnhth Before Tax }}$}

\section{The Analysis of Multiple Linear Regression}

Multiple Regression Model was employed to determine the effect of independent variables on the dependent variable. Multiple linear regression analysis was employed as it involved two or more independent variables. According to Sugiyono (2009: 211), the general model of regression analysis is as follows:

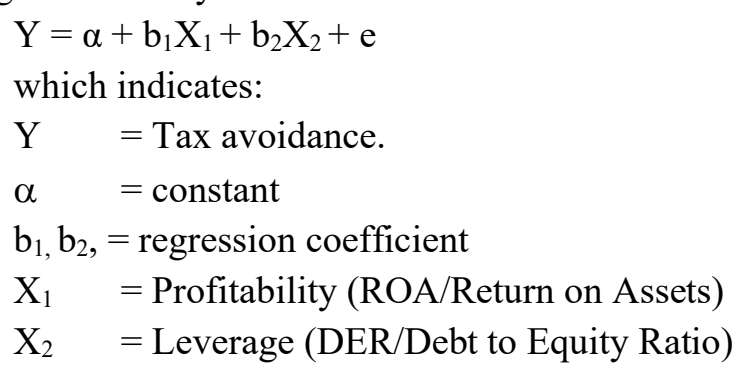

\section{Hypothesis Testing}

Hypothesis testing was carried out to prove whether the hypothesis was accepted or rejected, consisting of a simultaneous test ( $\mathrm{F}$ test) and a partial test ( $\mathrm{t}$-test and dominance effect test). 
a. F-Test (Simultaneous Test)

The $\mathrm{F}$ test (simultaneous test) basically revealed whether all the independent variables included in the model have a joint influence on the dependent variable. The $F$ test was utilized to determine whether the profitability variables (ROA (Return On Assets) and Leverage (DER (Debt to Equity Ratio) influenced tax avoidance.

b. The t-test (Partial Test)

The t-test was used to determine if each variable had effects on stock prices, by assuming that the other independent variables were considered constant. The basis for decision making was that the hypothesis would be accepted if the probability value of the $\mathrm{t}$-count error rate or $\mathrm{p}$-value was smaller than a certain level of significance (significance level of $5 \%)$.

\section{RESULTS AND DISCUSSION \\ Data Analysis and Interpretation \\ Results of Data Description}

This study aims to identify the effect of profitability and leverage on tax avoidance in food and beverage companies registered in the Indonesia Stock Exchange (IDX) in 2017-2019. The population of food and beverage companies registered in the Indonesia Stock Exchange covers 17 companies. This study employed a purposive sampling technique, i.e., a sampling technique based on certain predetermined criteria. The sampling criteria included (1) food and beverage companies registered in the Indonesia Stock Exchange/IDX in 2017-2019, (2) Companies that issue financial reports consecutively during 2017-2019, (3) Financial Statements providing information on the variables required, profitability, and leverage. The results of descriptive statistics regarding the data of variables used in this study after data processing are as follows:

Table 3.Results of Descriptive Statistic Analysis

Des criptive Statistics

\begin{tabular}{|l|r|r|r|r|r|}
\hline & \multicolumn{1}{|c|}{$\mathrm{N}$} & \multicolumn{1}{c|}{ Minimum } & Maximum & Mean & Std. Deviation \\
\hline tax_avoidance & 39 & .19861478 & .33375057 & .264110000 & .02998604428 \\
ROA & 39 & .0258065 & 1.0226495 & .172730627 & .2298855433 \\
LEV & 39 & .287840 & 3.028644 & 1.34008841 & .692207578 \\
Valid N (listw ise) & 39 & & & & \\
\hline
\end{tabular}

Source: processed primary data, 2020

From the table of descriptive statistics above, it can be explained as follows:

1. Tax avoidance

Tax avoidance in 13 samples of food and beverage companies had an average of 0.264110000 , with 0.19861478 as the lowest tax avoidance value and 0.33375057 as the highest tax avoidance value, while the standard deviation reached 0.2998604428 . The food and beverage company with the lowest tax avoidance value was PT. Siantar Top, Tbk in 2017, while the company with the highest tax avoidance value was PT. Sekar Laut, Tbk in 2019.

2. Return on Assets/ROA

ROA from 13 samples of food and beverage companies had an average of 0.172730627 , with 0.0258065 as the lowest value and 1.0226495 as the highest one, while the standard deviation amounted to 0.2298855433 . The food and beverage company with the lowest ROA was PT. Nippon Indosari Corpindo Tbk in 2017, while the company with the highest ROA was PT. Multi Bintang Indonesia, Tbk in 2019 


\section{Leverage}

Leverage on 13 samples of food and beverage companies had an average of 1.34008841 , with 0.287840 as the lowest value and 3.028644 as the highest one and standard deviation of 0.692207578 . The food and beverage company with the lowest leverage value was PT. Ultrajaya Milk Industry \& Trading Company, Tbk in 2017, while the company with the highest leverage value was PT. Multi Bintang Indonesia, Tbk in 2017.

\section{Results of Multiple Linear Regression Analysis}

Multiple linear regression analysis was used to identify the effect of profitability and leverage on tax avoidance in food and beverage companies registered in the Indonesia Stock Exchange in 2017-2019. The analysis was carried out using the SPSS application with a multiple linear regression model. The analysis results are presented in the following table.

Table 4. Results of Multiple Linear Regression

\begin{tabular}{|l|c|l|l|}
\hline Variable & Regression Coefficient (B) & t-count & Sig. \\
\hline Constant & 1.376 & 7.195 & 0.000 \\
\hline LN_ROA & 0.017 & 1.083 & 0.094 \\
\hline LN_LEV & 0.211 & 2.385 & 0.003 \\
\hline R2 & $=0.729$ & \\
\hline F-count & & $=7.187$ & \\
\hline Sig. & & $=0.000$ & \\
\hline
\end{tabular}

Source: Processed primary data, 2020

The results of the multiple linear regression analysis can be entered into the equation as follows:

LN_Tax avoidance $=1.376+0.017 \mathrm{LN} \_$ROA $+0.211 \mathrm{LN} \_\mathrm{LEV}$

The regression equation above can be interpreted as follows:

1. $\mathrm{a}$ (constant $)=1.376$, meaning that if there were no ROA and leverage variables, the amount of tax avoidance in food and beverage companies reached 1.376, assuming that other factors were constant (ceteris parimbus).

2. $b_{1}=0.017$. The LN_ROA regression coefficient of 0.017 indicates that ROA had a positive regression coefficient, meaning that every $1 \%$ increase in ROA would increase tax avoidance by $0.017 \%$ and vice versa, by assuming that other factors were constant (ceteris parimbus).

3. $\mathrm{b}_{2}=0.211$. The LN_leverage regression coefficient of 0.211 suggests that leverage had a positive regression coefficient, meaning that every $1 \%$ increase in leverage would increase tax avoidance by $0.211 \%$ and vice versa, assuming that other factors were constant (ceteris parimbus).

\subsubsection{Results of Hypothesis Testing}

The hypothesis proposed in this study was to test the effect of independent variables on the dependent variables jointly using a simultaneous test (F-test). Besides, a partial test ( $\mathrm{t}$ test) was applied to test the effect of the independent variables partially on the dependent variables.

\section{Results of Simultaneous Test (F-test)}

A simultaneous test was used to determine the effect of independent variables, ROA and leverage, simultaneously tax avoidance. If the probability of the F-count error rate is smaller than the significance level of 0.05 , the model tested is significant. For analyzing the significance of the proposed regression model, it is presented in the following table.

Table 5. Results of Simultaneous Test (F-test)

\begin{tabular}{|l|l|l|}
\hline F-count & Sig. & Conclusion \\
\hline 7.187 & 0.000 & Significant \\
\hline
\end{tabular}

Source: Processed primary data, 2020 
The table above shows the F-count value of 7.187 , with a probability that the error rate was lower than the expected significance level $(0.005<0.05)$. Therefore, it can be concluded that ROA and leverage variables simultaneously affected tax avoidance in food and beverage companies registered in the Indonesia Stock Exchange 2017-2019.

\section{Results of Partial Test (Regression Coefficient)}

The regression coefficient was used to determine the effect of ROA and leverage partially on tax avoidance in food and beverage companies. T-count was used to test the significance of the regression coefficient. If the probability of t-count error was smaller than a certain level of significance ( $5 \%$ significance), the independent variables had a significant effect on the dependent variables. The results of the regression coefficient testing using the SPSS program are presented below.

Table 6. Results of Partial Test

\begin{tabular}{|l|l|c|l|l|l|}
\hline No & \multicolumn{1}{|c|}{ Variable } & $\begin{array}{c}\text { Regression } \\
\text { coefficient }\end{array}$ & t-count & Sig. & \multicolumn{1}{|c|}{ Conclusion } \\
\hline 1 & ROA & 0.017 & 1.083 & 0.094 & Insignificant \\
\hline 2 & Leverage & 0.211 & 2.385 & 0.003 & Significant \\
\hline
\end{tabular}

Source: Processed primary data, 2020

Based on the partial test results in table 4.6 above, it can be explained as follows:

a. Testing on the effects of ROA on tax avoidance resulted in a regression coefficient of 0.017 and t-count of 1.083 with an error rate probability of 0.094 greater than the expected significance level $(0.094>0.05)$. Therefore, it can be concluded that ROA had no significant effect on tax avoidance in food and beverage companies in the Indonesia Stock Exchange in 2017-2019.

b. Testing on the effect of leverage on tax avoidance generated a regression coefficient of 0.211 and obtained a t-count of 2.385 with an error rate probability of 0.003 smaller than the expected significance level $(0.003<0.05)$. Therefore, it can be concluded that leverage had significant positive effects on tax avoidance in food and beverage companies on the Indonesia Stock Exchange in 2017-2019.

\section{Results of Dominance Effect Test}

The most influential independent variable on variable $\mathrm{Y}$ could be determined by comparing the standardized beta coefficient $(\beta)$ between one variable and another. To compare the standardized beta coefficient of each independent variable, Table 4.9 presents the value as follows:

Table 4. Standardized Beta Coefficient

\begin{tabular}{|l|c|}
\hline \multicolumn{1}{|c|}{ Variable } & $\begin{array}{c}\text { Standardized Beta } \\
\text { Coefficients }\end{array}$ \\
\hline LN_ROA & 0.144 \\
\hline LN_LEV & 0.267 \\
\hline
\end{tabular}

Source: processed primary data, 2020

Based on the table, it is known that the leverage variable was a variable with a standardized beta coefficient more significant than the ROA variable. It indicates that the leverage variable more dominantly influenced the tax avoidance variable (Y). 


\section{Discussion}

\section{Effects of Return on Assets/ROA to Tax Avoidance}

The regression coefficient value for ROA was 0.017 , while the t-count reached 1.083 , with an error rate probability of 0.094 greater than the expected significance level $(0.094>0.05)$. Therefore, it can be concluded that ROA had no significant effect on tax avoidance in food and beverage companies in the Indonesia Stock Exchange in 2017-2019. These results show a positive value, meaning that if the ROA increased, the tax avoidance in food and beverage companies in the Indonesia Stock Exchange in 2017-2019 would increase. Conversely, if the ROA decreased, the tax avoidance of food and beverage companies in the Indonesia Stock Exchange during 2017-2019 would also decrease.

The study results are congruent with Indarti's research (2018) entitled "Pengaruh Return on Assets, Leverage, Corporate Governance, dan Karakter Eksekutif terhadap Tax Avoidance," which states that ROA has no significant effect in tax avoidance practices.

\section{Effects of Leverage on Tax Avoidance}

The regression coefficient value of the leverage variable was 0.211 , while the $t$-count reached 2.385 , with an error rate probability of 0.003 smaller than the expected significance level $(0.003<0.05)$. Therefore, it can be concluded that leverage had significant positive effects on tax avoidance in food and beverage companies on the Indonesia Stock Exchange in 20172019.

These results suggest a positive value, meaning that if the leverage increased, the tax avoidance in food and beverage companies on the Indonesia Stock Exchange in 2017-2019 would increase as well. Conversely, if the leverage decreased, the tax avoidance in food and beverage companies on the Indonesia Stock Exchange in 2017-2019 would also decrease. The results of this study are in line with the results of Indarti's (2018) research entitled "Pengaruh Return on Assets, Leverage, Corporate Governance, dan Karakter Eksekutif terhadap Tax Avoidance," which states that leverage has a significant effect on tax avoidance practices.

\section{IV.CONCLUSION}

Based on the overall research results, the conclusion can be drawn as follows:

1. ROA and leverage variables simultaneously affect tax avoidance in food and beverage companies registered in the Indonesia Stock Exchange (IDX).

2. The ratio variable of ROA does not have a significant effect on tax avoidance in the food and beverage companies registered in the Indonesia Stock Exchange in 2013-2015. Meanwhile, leverage has a significant positive impact on tax avoidance in food and beverage companies registered in the Indonesia Stock Exchange.

3. Leverage variable has a dominance effect on tax avoidance in food and beverage companies registered in the Indonesia Stock Exchange.

\section{SUGGESTIONS}

Based on the research results, the researcher provides some suggestions as follows:

1. For investors Investors should pay more attention to ROA and leverage because they provide simultaneous effects on tax avoidance.

2. For Further Research

Regarding factors influencing tax avoidance, it is expected to expand the research population or compare it with other sectors. 


\section{REFERENCES}

[1] Agus Harjito and Martono. 2008. Manajemen Keuangan. Yogyakarta: EKONOSIA

[2] Armstrong, M. 2014. Performance Management. England Clays. St. Ives Ple

[3] Annisa, N. A. dan Kurniasih, L. 2012. Pengaruh Corporate Governance terhadap Tax Avoidance. Jurnal Akuntansi dan Auditing. 8(2).

[4] Bambang, Riyanto. 2008. Dasar-dasar Pembelanjaan Perusahaan. Fifth Edition. Yogyakarta: BPFE UGM

[5] -----------. 2010. Dasar-dasar Pembelanjaan Perusahaan. Sixth Edition. Yogyakarta: BPFE UGM

[6] Budiman, Judi and Setiyono. 2012. Pengaruh Karakter Eksekutif Terhadap Penghindaran Pajak (Tax Avoidance). Simposium Nasional Akuntansi XV. Banjarmasin.

[7] Chen, S, X. Chen, Q. Cheng, and T. Shevlin. 2010. Are Family Firms More Tax Avoidance Aggressive Than Non-Family Firms?. Journal of Financial Economics. 95: 41-61.

[8] Darmadji T and Fakhrudin M.H. 2008. Pasar Modal di Indonesia Pendekatan Tanya Jawab. Jakarta: Salemba Empat

[9] Dendawijaya Lukman. 2008. Manajemen Perbankan, Second Edition. Jakarta : Ghalia Indonesia.

[10] Dewi, Ni Nyoman Kristiana, \& Jati, I Ketut. 2014. Pengaruh Karakter Eksekutif, Karakteristik Perusahaan, dan Dimensi Tata Kelola Perusahaan Yang Baik pada Tax Avoidance di Bursa Efek Indonesia. E-Jurnal Akuntansi Universitas Udayana, Vol. 6, No. 2, pp. 249-260.

[11] Dina, Rahmawati. 2012. Analisis Faktor-Faktor yang Berpengaruh Terhadap Praktik Perataan Laba (Studi Pada Perusahaan Manufaktur yang terdaftar di BEI tahun 20012010). Diponegoro Journal of Accounting. Vol. 1, No.2.

[12] Dyreng, Scott D. Hanlon, Michelle 2009. The Effect of Executives on Corporate Tax Avoidance. Sosial Science Reserach Network.

[13] 2010. The Effects of Executives on Corporate Tax Avoidance. The Accounting Review, Vol 85, No 4, pp 163-189.

[14] Ghozali, Imam. 2009. Aplikasi Analisis Multivariate dengan program SPSS (4 ${ }^{\text {th }}$ ed). Semarang: Badan Penerbit Universitas Diponegoro.

[15] Godfrey, Jayne M. et al. 2010. Accounting Theory. Seventh Edition. New York: John Wiley and Sons, Inc.

[16] Halim, Abdul. 2008. Analisis Investasi. Jakarta: Salemba Empat.

[17] Hanum, Hashemi Rodhian, and Zulaikha. 2013. Pengaruh Karakteristik Corporate Governance Terhadap Effective Tax Rate (Studi Empiris Pada BUMN yang terdaftar di BEI 2009-2011). Journal Vol.2 No. 2. Universitas Diponegoro.

[18] Hartono, Jogiyanto. 2008. Teori Portofolio Dan Analisis Investasi. Yogyakarta: BPFE

[19] Husnan, Suad., Pudjiastuti, Enny. 2012. Dasar-Dasar Manajemen Keuangan. Third Edition. Yogyakarta: UPP AMP YKPN.

[20] Kasmir. 2008. Manajemen Perbankan. Jakarta: PT. Rajagrafindo Persada.

[21] Kuswadi. 2008. Memahami Rasio-rasio Keuangan Bagi Orang Awam. Jakarta : Gramedia

[22] Mamduh, M Hanafi, and Abdul, Halim. 2009. Analisis Laporan Keuangan. Yogyakarta: UPP STIM YPKN.

[23] Mardiasmo. 2009. Perpajakan Edisi Revisi 2009. Yogyakarta: Penerbit Andi.

[24] Meilinda, M. and N. Cahyonowati. 2013. Pengaruh Corporate Governance terhadap Manajemen Pajak. Diponegoro Journal of Accounting. 2 (3): 1-13.

[25] Noor, Md Rohaya et al. 2010. Corporate Tax Planning: A Study on Corporate Effective Tax Rates of Malaysian Listed Company. International Journal of Trade. Economics and Finannce, Vol.1 No.2. 
[26] Ozkan, Aydin. 2011. Determinats of Capital Structure and Adjustment to Long Run Target: Evidence from UK Company Panel Data. Journal Business Finance \& Accounting. Pp 175198

[27] Prakosa, K.B. 2014. Pengaruh Profitabilitas, Kepemilikan Keluarga, dan Corporate Governance terhadap Penghindaran Pajak di Indonesia. Simposium Nasional Akuntansi XVII. Mataram, Indonesia. Pp 1-27.

[28] Richardson, G., Lanis, R. 2009. Determinants of Variability in Corporate Effective Tax Rates and Tax Reform: Evidence from Australia. Journal of Accounting and Public Policy, 26 (2007), 689-704.

[29] Sartono, Agus. 2008. Manajemen Keuangan. Buku II. Yogyakarta: UPP AMP YKPN.

[30] Samsul, Mohamad. 2008. Pasar Modal dan Manajemen Portofolio. Jakarta: Erlangga

[31] Siahaan, Hinsa. 2008. Teori Optimalisasi Struktur Modal dan Aplikasinya di dalam Memaksimumkan Nilai Perusahaan. Jurnal Keuangan dan Moneter. Volume 7 No. 1.

[32] Sudana, I. 2011. Manajemen Keuangan Perusahaan Teori dan Praktek. Jakarta: Erlangga

[33] Supriyono, R.A. 2008. Perencanaan dan Pengendalian Biaya Serta Pembuatan Keputusan. BPFE. Yogyakarta

[34] Suyanto, K.D., \& Supramono. 2012. Likuiditas, Leverage, Komisaris Independen dan Manajemen Laba terhadap Agresivitas Pajak Perusahaan. Jurnal Keuangan dan Perbankan, 2 (16), 167-177.

[35] Uppal J.S. 2008. Kasus Penghindaran Pajak di Indonesia. Economic Review Journal, 201.

[36] Tandelilin, Eduardus. 2010. Portofolio dan Investasi Teori dan Aplikasi. First Edition. Yogyakarta: Kanisius 